\title{
PERCEPTION OF LOCUS OF CONTROL, LEVEL OF EDUCATION, MACHIAVELLIANISM AND ETHICAL REASONING AGAINST AUDITOR BEHAVIOR IN AUDIT CONFLICT SITUATIONS
}

\author{
Widya Ais Sahla \\ Accounting Department, Politeknik Negeri Banjarmasin \\ ais.sahla@akuntansipoliban.ac.id \\ Emy Iryanie \\ Accounting Department, Politeknik Negeri Banjarmasin \\ jasmine_emy@yahoo.com
}

Received:03-06-2018

\section{ABSTRACT}

This study aims to examine individual factors such as locus of control (LOC), level of education, Machiavellianism and ethical reasoning that may influence the behavior of auditors in conflict situations. The survey was conducted by using questionnaires to auditors working at Public Accounting Firm in South Kalimantan. The analysis technique used is with multiple regressions. The results show that individual factors such as locus of control (LOC), level of education, Machiavellianism and ethical reasoning

Accepted: $14-10-2018$ have been shown to significantly affect auditor behavior in conflict situations.

Keywords: Audit Conflict; Ethical Reasoning; Level of Education; Locus of Control (LOC); Machiavellianism.

How to cite: $\begin{aligned} & \text { Sahla, W. A., \& Iryanie, E. (2018). Perception of Locus of Control, Level of Education, } \\ & \\ & \text { Machiavellianism and Ethical Reasoning Against Auditor Behavior in Audit Conflict Situations. } \\ & \text { Akrual: Jurnal Akuntansi. } 10 \text { (1): 15-26. doi: http://dx.doi.org/10.26740/jaj.v10n1.p15-26 }\end{aligned}$

\section{INTRODUCTION}

Good corporate governance issues have been raised in recent times. In an effort to achieve good corporate governance, the auditor plays a crucial role as a profession based on the trust of the community to provide its professional services to the parties concerned. Trust given should be professionally accountable by providing quality audit results. Therefore, in carrying out its duties the auditor must act objectively and independently based on the code of ethics of their profession.

Nature of the work of the auditor itself is considered ambiguous which in certain situations will complicate even cornering auditors. On the one hand, auditors are required to be subject to professional standards and codes of ethics during their audit work. However, on the other hand, the fees from the auditor's work are actually provided by the clients who hire them so that it takes a hard effort for them to stick to the professional standards and codes of conduct. This fact is the obstacle for the auditor in maintaining objectivity and independence.

In various audit work, auditors are often not as understanding with the client as to the aspects of the function and purpose of the examination. In this case the client may pressure the auditor to take action in accordance with the wishes of the client which is an action that violates professional standards. Meeting the client's desire means violating the standards but 
the rejection of the client's request can result in sanctions in the possibility of termination of the assignment (dismissal) and very detrimental to the auditor. In this situation, auditors are said to be in a conflict where they are bound by professional standards and ethics on one hand and yet demanded to perform an action that violates the standards and ethics as well as threat its objectivity and independence by the client who hire them.

Conflict are common in auditoria work. It is a process that begins when one party feels let down by the other (French and Allbright, 1998). Moreover, according to Fried and Schiff (1981) the frequency of conflict between management and the Public Accounting Firm has been increased lately.

Knapp (1985) examined how certain contextual factors in conflict between auditors and clients will affect the auditor's ability to resist client pressure. The results suggest that there are four factors that allegedly influence the users' perceptions of the financial statements of the nature of the conflict problem, the client's financial condition, the granting of Management Advisory Services (MAS) by the Firm, and the level of competition in the market.

It seems that conflicts can only be addressed through a moral approach, so ethical reasoning and concerns are essential in any auditor's professional judgment. Today a great deal of research is devoted to this issue, and attempts to describe and evaluate factors that may influence the auditor's ethical behavior
(Louwes et al., 1997 in (Muawanah and Indriantoro, 2001).

Factors that may influence the auditor's ethical behavior have been investigated by (Tsui and Gul, 1996); (Zoraifi, 2005); (Hidayat and Handayani, 2010). The interaction effects of locus of control, personality variables, and ethical reasoning on auditor behavior in situations of audit conflict. The implication of the result is that the explicit recognition of the locus of control and ethical reasoning provides a better explanation for differences in ethical decision making auditors. Zoraifi (2005) developed Tsui and Gul (1996) researched by adding two variables of personality, namely the level of education and work experience to the auditor's behavior in dealing with audit conflict situations. The result is that both of these personality variables influence the auditor's behavior in dealing with situations of audit conflict.

The development of research on auditors in the face of audits by Hidayat and Handayani (2010) by adding self efficacy variables. Self efficacy is operated as a person's belief in his ability to perform activities successfully. Auditors with high self efficacy will perform tasks to succeed and in accordance with the code of ethics as auditors that will enable ethical behavior. Their results support research conducted by Lee and Bobko (1994) that individuals with self-efficacy of the same type can have different ethical measures that will behave differently. 
Richmond (2003) found evidence that the individual's personality influences ethical behavior by investigating the Machiavellianism relationship that forms a personality type called Machiavellian attributes and ethical reasoning with individual behavioral trends in the face of ethical dilemmas. The results of this study indicate that the higher tendency of one's Machiavellian traits the more likely it is to behave unethically and the higher the level of one's ethical judgment, the more ethical it behaves.

Based on the above description, this study is an extension of Tsui and Gul (1996) research by incorporating a new personality variable that is Machiavellianism into the model to be tested. This Machiavellianism is also a suggestion of future research in Hidayat and Handayani (2010) research. This study aims to examine the role of individual factors and ethical reasoning of auditors in situations of audit conflict.

\section{LITERATURE REVIEW}

\section{Perception}

Perception was a process by which individuals organize and interpret their sense impression to give meaning to their environment (Robbins, 1997). Perception is a process preceded by sensing, interpreting and interpreting messages.

According to Rakhmat (2007), perception was influenced by attention, personal factor (functional) and situational factors. Functional factors derived from the needs, past experience and other things that are personal so that the characteristics of people who provide a response that will determine the perception. Whereas the structural factors derive solely from the nature of the physical stimuli and the nerve effects it produces on the individual nervous system. Gordon (1993) states perceptions as sensory processes capture the stimuli of the real environment, then understood and produces human insight into the stimulus.

From the above definitions, can be concluded that perception is a process of giving meaning that starts from the acceptance of stimuli to be used to interpret and understand the world around.

\section{Audit Conflict}

According to Kenneth Thomas (1976) in Hidayat and Handayani (2010), conflict was a process whereby a part, both individuals and groups feel that other parts (both individuals and groups) take actions contrary to their interests. Some business practitioners see that all conflicts were a nuisance and they assume that their job is to eliminate the conflict (Schwartz, 1992 in Hidayat and Handayani, 2010).

In an audit environment, conflicts are also viewed as a disturbance that can threaten the auditor's objectivity and independence. The research that became many references in this topic is the research of (Knapp, 1985). Knapp (1985) suggested that better outcomes of audit conflicts will be obtained when clients' financial condition is good compared to clients with poor financial conditions. 
AKRUAL: Jurnal Akuntansi, volume 10, issue 1, October 2018 (15-26)

Tsui and Gul (1996) examined the interaction between locus of control (LOC) and ethical reasoning of auditor behavior in situations of audit conflict. Their research investigated the interaction effects of locus of control (LOC), personality variables, and ethical reasoning. The samples studied were 80 experienced auditors from Big 6 and Non-Big 6 Public Accounting Firm in Hong Kong who provided case studies involving them in situations of audit conflict and asked to state the extent to which they would approve the client's request. Data analysis used multiple regression and found that ethical reasoning moderated the relationship between the locus of control (LOC) and the auditor's response to approve the client's request in an audit conflict situation.

\section{Ethical Reasoning}

In generally, ethical behavior can be interpreted as a behavior that conforms to generally acceptable social norms with respect to beneficial and harmful actions. As members of a profession, auditors have an obligation to maintain their ethical standards of conduct to organizations in which they are sheltering, their profession, society and themselves and have a responsibility to be competent and maintain their objectivity and independence.

According to Khomsiyah and Indriantoro (1998) ethical consciousness/ethical sensitivity is the ability to realize the existence of ethical or moral values in a decision. With the existing ethical awareness of the auditor in conducting an examination, then someone will be able to assess what to do and which should not be done in a decision-making.

Cognitive Moral Development Theory is useful in describing the psychology of making ethical reasoning in the domain of public accountants (Ponemon, 1992). Ponemon (1992) argued that development to as higher level of ethical consideration will help the sensitivity of an individual to better criticize events, problems and conflicts. Auditors with high ethical reasoning will be better at dealing with conflict and ethical dilemmas. Ponemon and Gabhart (1990), Trevino (1986) and Trevino and Youngblood (1990) suggest that individuals whose ethical reasoning are higher are likely to be less likely to approve unethical behavior. Ponemon (1992) compared ethical reasoning as measured by the DIT between partners and managers, his research results indicate that partners and managers at a higher level of ethical consideration will be more independent in making decisions related to ethical dilemmas.

\section{Locus of Control (LOC)}

In the last few decades, the concept of locus of control gained attention in the psychological literature. Rotter (1996) in Chan and Leung (2006) stated that the locus of control is an act whereby individuals connect events in their lives with actions or forces beyond their control. Rotter (1996) in Chan and Leung (2006) identified two types of individuals based on locus of control: internal and external. Those 
with internal locus of control believe that results in their lives depend on their own actions. On the other hand, those with external locus of control believe that the outcome of life depends on chance, fate or other powerful influential people (Rotter, 1996 in Chan and Leung, 2006).

Trevino (1986), as quoted by Muawanah (2000), states that personal variables such as LOC can interact with ethical awareness to influence individual behavior in ethical dilemmas (Tsui and Gul, 1996). Thus the relationship between the LOC and the auditor's behavior may depend on the auditor's ethical consciousness. Meanwhile, Rotter (1966) in (Muawanah, 2000), argued that internal-external constructs as personal variables such as LOC are relatively more stable than ethical awareness, because the level of ethical consciousness can be increased through ethical intervention and formal education. The results of both studies suggest that the interaction between LOC and ethical awareness affects auditor behavior in situations of audit conflict. More specifically, Tsui and Gul (1996) have found a positive interaction between locus of control (LOC) and auditor behavior in situations of audit conflict.

Alternative hypothesis proposed are:

\section{H1: The interaction between locus of control (LOC) and ethical reasoning has a positive effect on auditor behavior in situations of audit conflict.}

\section{Level of Education}

According to Kamus Besar Bahasa Indonesia, education is defined as a process of learning for individuals to achieve higher knowledge and understanding about certain objects and specific. Such knowledge is formally acquired which results in the individual having a mindset and behavior in accordance with the education he has acquired.

Education plays a crucial role in many cases including ethical issues. Assessment of individual ethical standards differs from the educational level (Keller et.al, 2007). However, accounting and business education did not have a positive effect on ethical developments (McCabe, 1994 and Gray, 1994 in (McPhail and Walters, 2009). Kum-Lung and Teck-Chai (2010) in his research indicate that the level of education affects one's ethical perceptions. There is a difference between "Malaysian Study Sijil" (equivalent to Diploma) with undergraduate and graduate students. Undergraduate and postgraduate students have a higher average grade in their ethical perceptions than students at the Diploma level.

Kraft and Singhapakdi (1991) conducted a study comparing S1 students with graduate students. Students are given a situation in which the supervisor discloses results on personality tests without permission. It was found that undergraduates perceive supervisor actions as more moral when there is increased production. While the $\mathrm{S} 2$ students assume that the action is unethical even in situations of increased production.

Zoraifi (2005) had found a significant interaction between educational levels with ethical reasoning of auditor behavior when 
experiencing conflict situations. Individuals with the same level of education can have different ethical reasoning that will behave differently.

Based on the results of previous studies both found that the levels of education affect the ethical perceptions and who found that the educational level does not affect one's ethical perceptions, the hypothesis tested is:

H2: The interaction between educational level and ethical reasoning positively affects auditor behavior in situations of audit conflict.

\section{Machiavellianism}

Machiavellianism is operated as a variable in which an individual with an unscrupulous reputation relates to others to achieve his own personal goals, and to manipulate others for his own purposes (Christie and Geis, 1970). In the current situation Machiavellian moves aggressively, manipulatively, exploit, and move cunningly to achieve personal or organizational goals (Calhoon, 1969). Kohlberg (1981)explains that ethical orientation has to do with ethical dimensions like Machiavellianism.

This Machiavellian scale had become the proxy of moral behavior that influences the behavior of ethical decision making (Hegarty and Sims (1978) and (1979) and Trevino et al. (1985) in Purnamasari (2006)). So it is expected that individuals with high Machiavellian properties will be more likely to perform unethical actions than individuals with low Machiavellian properties. Jones and Kavanagh (1996) and Richmond (2003) found individuals with high machiavellian properties would be more likely to perform unethical actions than individuals with low machiavellian properties. Therefore, it is possible for auditors with high machiavellian properties to behave unethically in situations of audit conflict. However, when auditors who possess high machiavellian attributes coupled with high ethical reasoning, are likely to be better at dealing with conflict and ethical dilemmas. So the hypothesis is formulated as follows:

\section{H3: The interaction between the level of Machiavellianism and ethical rea- soning has a positive effect on auditor behavior in situations of audit conflict.}

\section{RESEARCH METHODS}

\section{Selection and Sampling Techniques}

The sample of this research is auditor at 2 (two) Public Accounting Firm in South Kalimantan, that is Drs. Fahmi Rizani and Drs. Gusti Mahfoedz. Data is obtained from Indonesian Institute of Accountants Directory (IAI). Table 1 below contains a description of the results of questionnaire data collection

\section{Table 1. Data Collection Results}

\begin{tabular}{lcc}
\hline \multicolumn{1}{c}{ Information } & Amount & Percentage \\
\hline Distributed & 35 & 100 \\
questionnaires & & \\
Questionnaires did not & 0 & 0 \\
returns & 35 & 100 \\
$\begin{array}{l}\text { The return } \\
\text { questionnaires } \\
\text { Incomplete } \\
\text { questionnaires } \\
\text { Qualified questionnaires }\end{array}$ & 32 & 8.57 \\
\hline
\end{tabular}

Source: Data process 


\section{Operational Definition And Variable} Measurement

\section{Auditor Behavior Under Audit Conflict} Situations

The dependent variable of auditor behavior in situations of audit conflict is measured through the extent to which the auditor is willing to meet the client's pressure in a conflict situation ie a situation that occurs when the auditor and client disagree in one aspect of the audit function which is an indicator of auditor behavior in ethical decision making. The instrument used is a short case developed by Knapp (1985) that has been adopted by Tsui and Gul (1996). Respondents are asked to take a decision in a case faced by accepting or rejecting the client's request. Ethical and independent behavior is the answer of respondents who reject the client's request while unethical and independent behavior is the answer of respondents who meet the client's request.

\section{Ethical Reasoning}

Operated as an individual's ability to evaluate and consider ethical values in an event. The ethical reasoning variables were measured using an instrument developed by Cohen et.al (1998), the Multidimensional Ethic Scale (MES). The instrument used in this research consisted of three kinds of moral collapse, namely justice, utilitarianism and culture relativism with three case illustrations such as that used by Susanty (2002) and Zoraifi (2005).

\section{Locus of Control (LOC)}

The locus of control variable is operated as an internal-external construct that measures a person's beliefs about events affecting his or her life. This study uses the Workplace Locus of Control (WLCS) scale developed by Spector (1998) in Reiss and Mitra (1998). This instrument contains 16 statements and respondents are asked to choose the answer that best suits them. Categorization of respondents into internal and external set with means split. If the respondent's answer is above average, it is classified as internal and vice versa, if below average then it is classified externally.

\section{Level of Education}

Education level is defined as the level of formal education achieved by an individual. Information on the level of education was obtained from the respondents' demographic data at the end of the questionnaire.

\section{Machiavellianism}

These variables are operated as the tendency of individuals to utilize the situation to gain personal gain and more have a desire to disobey the rules and become unethical (individuals with high Machiavellian properties). Perceptions of Machiavellian properties are measured by Mach IV scale developed by Christie and Geis (1970). The higher the score of Mach IV, the greater its machiavellian properties. 


\section{RESEARCH METHODS}

In accordance with Tsui and Gul (1996), multiple regression models proposed in this study are:

$Y=\propto+\beta_{1} X_{1}+\beta_{2} X_{2}+\beta_{3} X_{3}+\beta_{4} X_{1} \cdot X_{4}+\beta_{5} X_{2} \cdot X_{4}+\beta_{6} X_{3} \cdot X_{4}+\varepsilon$

Information:

\begin{tabular}{|c|c|c|}
\hline Y & $=$ & $\begin{array}{l}\text { Auditor behaviour in situations of audit } \\
\text { conflict }\end{array}$ \\
\hline$\alpha$ & $=$ & Constants \\
\hline$\beta_{1}-\beta_{5}$ & $=$ & Regression coefficient \\
\hline $\mathrm{X}_{1}$ & $=$ & Locus of control \\
\hline $\mathrm{X}_{2}$ & $=$ & Education level \\
\hline $\mathrm{X}_{3}$ & $=$ & Machiavellian \\
\hline$X_{1} \cdot X_{4}$ & $=$ & $\begin{array}{l}\text { Interaction between the locus of control } \\
\text { with ethical reasoning }\end{array}$ \\
\hline$X_{2} \cdot X_{4}$ & $=$ & $\begin{array}{l}\text { Interaction between level of education } \\
\text { with ethical reasoning }\end{array}$ \\
\hline$X_{3} \cdot X_{4}$ & $=$ & $\begin{array}{l}\text { Interaction between machiavellianism } \\
\text { with ethical reasoning }\end{array}$ \\
\hline & 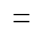 & Error term \\
\hline
\end{tabular}

\section{ANALYSIS AND DISCUSSION}

\section{RESEARCH RESULT}

\section{Demographic Data of Respondents}

The description of respondents demographic data can be seen in table 2 below.

Table 2. Respondent Demographic Data

\begin{tabular}{lcc}
\hline \multicolumn{1}{c}{ Information } & Amount & Percentage \\
\hline $\begin{array}{l}\text { Distributed } \\
\text { questionnaires }\end{array}$ & 35 & 100 \\
$\begin{array}{l}\text { Questionnaires did not } \\
\text { returns }\end{array}$ & 0 & 0 \\
$\begin{array}{l}\text { The return } \\
\text { questionnaires } \\
\begin{array}{l}\text { Incomplete } \\
\text { questionnaires } \\
\text { Qualified questionnaires }\end{array}\end{array}$ & 35 & 100 \\
\end{tabular}

\section{Source: Data process}

\section{Descriptive Statistics}

The following table 3 is used to provide an overview of the variables in this study.
Table 3. Descriptive Statistics

\begin{tabular}{lccccc}
\hline & $\mathrm{N}$ & $\begin{array}{c}\text { Minimu } \\
\mathrm{m}\end{array}$ & $\begin{array}{c}\text { Maxi } \\
\text { mum }\end{array}$ & Sum & $\begin{array}{c}\text { Std. } \\
\text { Deviation }\end{array}$ \\
\hline $\begin{array}{l}\text { Auditor_ } \\
\text { behaviour }\end{array}$ & 32 & 100 & 60 & 920 & 14.75608 \\
$\begin{array}{l}\text { Ethical_ } \\
\text { reasoning }\end{array}$ & 32 & 5 & 6 & 178 & 0.39201 \\
MACH & 32 & 3.4 & 5.1 & 141 & 0.59714 \\
LOC & 32 & 1.94 & 3.31 & 85 & 0.45013 \\
LOE & 32 & 3 & 5 & 104 & 0.67202 \\
\hline
\end{tabular}

Source: Data process

\section{Validity and Reliability Test}

The validity test for the locus of control variables shows that the correlation between each question (LOC1 to LOC16) to the total construct score (LOC) shows significant results except for LOC14 with a score of 0.176 which is not significant and excluded from the research model. Similarly, for the validity test of variables Machiavellianism (MACH1 up to $\mathrm{MACH} 20$ ) also showed significant correlation between each question to the total score of its construct (MACH) except for MACH4, MACH6, MACH7, MACH9, MACH10 and MACH11 with each score of $0.273,0.270$, $0.021,-0.293,-0.0293$, and 0.270 are insignificant and excluded from the research model. Then the result of validity test to ethical consideration variable shows that the correlation between each question (ethical_reasoning1 up to ethical_reasoning3) to total score of construct Ethical reasoning obtained significant result.

Reliability test results for the dependent variable and moderating variables also show reliable results. The resulting cronbach alpha value is 0.804 for the LOC construct, 0.950 for 
the MACH construct and 0.756 for the Ethical_reasoning construct that has met the criteria, so that the locus of control, Machiavellianism and ethical variables used are reliable.

\section{Hypothesis Testing}

The test results of the three hypotheses proposed in this study are presented in SPSS 17 output table below.

Table 4. Hypothesis Testing Results

\begin{tabular}{lccccc}
\hline & \multicolumn{2}{c}{$\begin{array}{c}\text { Unstandarized } \\
\text { Coefficients }\end{array}$} & $\begin{array}{c}\text { Standarized } \\
\text { Coefficients }\end{array}$ & & \\
\cline { 2 - 4 } Model & B & $\begin{array}{c}\text { Std. } \\
\text { Error }\end{array}$ & Beta & & \\
\cline { 2 - 4 } (Constant) & 129.127 & 39.266 & & 3.289 & .003 \\
MACH & 403.018 & 84.072 & 16.309 & 4.794 & .000 \\
LOC & 225.675 & 74.879 & 6.884 & 3.014 & .006 \\
LOE & -849.303 & 170.668 & -38.679 & -4.976 & .000 \\
Interaction 1 & -39.237 & 13.388 & -6.319 & -2.931 & .007 \\
Interaction 2 & 139.492 & 28.288 & 44.042 & 4.931 & .000 \\
Interaction 3 & -68.742 & 14.257 & -12.812 & -4.822 & .000 \\
\hline
\end{tabular}

a. Dependent Variable: auditorbehaviour Source: Data process

First Hypothesis Testing $\left(\mathrm{H}_{1}\right)$

The first hypothesis $\left(\mathrm{H}_{1}\right)$ tests the interaction between the locus of control with ethical reasoning of the auditor's behavior in situations of audit conflict. In table 4 it shows that the interaction1 value which is the interaction between locus of control (LOC) with ethical consideration (Ethical reasoning) is significant with $\mathrm{p}<0.05$ ( $\mathrm{p}=0.007)$. So it can be stated that Ethical Consideration variable is a moderating variable. It can be concluded also that $\mathrm{H}_{1}$ is accepted which means that the interaction between locus of control and ethical reasoning has a significant positive effect on auditor behavior in situations of audit conflict. This finding also supports the previous empirical findings of previous researchers such as Rotter (1996) in Chan and Leung (2006), Trevino (1986), and Tsui and Gul (1996) and Zoraifi (2005).

\section{Second Hypothesis Testing $\left(\mathrm{H}_{2}\right)$}

The second hypothesis $\left(\mathrm{H}_{2}\right)$ examines the interaction between level of educations with ethical reasoning to auditor behavior in situations of audit conflict. The interaction value 2 in table 4 is an interaction between level of education with a significant ethical consideration (Ethical reasoning) $(p=0.000)$. So it can be concluded also that $\mathrm{H}_{2}$ is supported statistically which means that the interaction between level of education and ethical reasoning have a significant effect on auditor behavior in situations of audit conflict. This finding is in line with the findings of Zoraifi (2005) which finds an interaction significance between level of education and ethical reasoning of auditor behavior in situations of audit conflict.

\section{Third Hypothesis Testing $\left(\mathrm{H}_{3}\right)$}

The third hypothesis $\left(\mathrm{H}_{3}\right)$ examines the interaction between Machiavellianism and ethical reasoning of auditor behavior in conflict situations. Table 4 shows that $\mathrm{H}_{3 \mathrm{~s}}$ is significant with $\mathrm{p}<0.05(\mathrm{p}=0.000)$ and it can be concluded that $\mathrm{H}_{3}$ is supported. These findings are consistent with research conducted by Jones and Kavanagh (1996) and Richmond (2003) who 
found that individuals with high machiavellian properties would be more likely to perform unethical actions than individuals with low Machiavellian properties. In this case auditors with high Machiavellian levels will tend to perform unethical acts by satisfying clients' requests in situations of audit conflict and vice versa for low level Machiavellian auditors will tend to be more ethical.

\section{CONCLUSIONS}

Conflict is a common phenomenon encountered in various occupational situations, especially in the area of auditing ie conflict between auditors and clients. The phenomenon of conflict between the auditor and the client at a certain point will be able to threaten the independence of the auditor and may result in low quality audit produced. This study provides a proof of the Cognitive Moral Development Theory that provides a psychological picture of making ethical considerations in the domain of public accountants. Higher ethical considerations will help the sensitivity of an individual to better criticize events, problems and conflicts (Ponemon, 1992). Auditors with high ethical considerations will be better at dealing with conflict and ethical dilemmas and that individuals with higher ethical considerations are less likely to approve unethical behavior.

The next finding, the individual factor that is the level of education also proved to affect the behavior of auditors in situations of audit conflict. These results confirm that accounting and business education have a positive effect on ethical development. Machiavellian proved to be negatively related to the independence and ethical conduct of the auditor. This means that auditors who have high Machiavellian traits will tend to approve irregularities against independence and tend to behave unethically by approving client requests in situations of audit conflict.

Limitations in this study are the sample of this study is limited to auditors at the Public Accounting Firm in South Kalimantan which in number of course is very limited so that the generalization of the results is still not appropriate in describing the behavior of auditors as a whole. Future research may expand the sample of the study. Future research can also examine other individual factors that may affect auditor behavior in conflict situations.

\section{ACKNOWLEDGMENTS}

The research is fully funded by Direktorat Riset dan Pengabdian Masyarakat, Direktorat Jenderal Penguatan Riset dan Pengembangan, Kementerian Riset, Teknologi dan Pendidikan Tinggi with the Research Contract No: 026/SP2H/LT/DRPM/IV/2017.

The authors express their gratitude and appreciation to Direktorat Riset dan Pengabdian Masyarakat, Direktorat Jenderal Penguatan Riset dan Pengembangan for opportunities and beliefs. 


\section{REFERENCES}

Calhoon, R. P. (1969). Niccolo Machiavelli and the Twentieth Century Administrator. Academy of Management Journal, 12(2), 205-212. doi:10.2307/254816

Chan, S. Y. S., \& Leung, P. (2006). The Effects of Accounting Students' Ethical Reasoning and Personal Factors on Their Ethical Sensitivity. Managerial Auditing Journal, 21(4), 436-457.

DOI:https://doi.org/10.1108/02686900610 661432

Christie, R. (1970). Scale Construction. Studies in Machiavellianism, 10-34. doi:10.1016/b978-0-12-174450-2.50007-5

Cohen, J. R., Pant, L. W., \& Sharp, D. J. (1998). The effect of gender and academic discipline diversity on the ethical evaluations, ethical intentions and ethical orientation of potential public accounting recruits. Accounting Horizons, 12(3), 250. DOI: 10.12691/education-2-3-2

French, W., \& Allbright, D. (1998). Resolving a Moral Conflict through Discourse. Journal of Business Ethics, 17(2), 177-194. DOI: https://doi.org/10.1023/A:1005792208264

Fried, D., \& Schiff, A. (1981). CPA switches and associated market reactions. The Accounting Review, 56(2), 326-341.

Gordon, J. R. (1993). A Diagnostic Approach to Organizational Behavior.

Hidayat, W., \& Handayani, S. (2010). Peran faktor-faktor individual dan pertimbangan etis terhadap perilaku auditor dalam situasi konflik audit pada lingkungan inspektorat Sulawesi Tenggara. Jurnal Mitra Ekonomi Dan Manajemen Bisnis, (1), 83-112.

Jones, G. E., \& Kavanagh, M. J. (1996). An experimental examination of the effects of individual and situational factors on unethical behavioral intentions in the workplace. Journal of Business Ethics, 15(5), 511-523.

Keller, A. C., T. Smith, K., \& Smith, L. M. (2007). Do gender, educational level, religiosity, and work experience affect the ethical decision-making of U.S. accountants? Critical Perspectives on Accounting, 18(3), 299-314.
Khomsiyah, K., \& Indriantoro, N. (1998). Pengaruh Orientasi Etika terhadap Komitmen dan Sensitivitas Etika Editor Pemerintah di Jakarta. The Indonesian Journal of Accounting Research, 1(1).

Knapp, M. C. (1985). Audit Conflict: An Empirical Study of the Perceived Ability of Auditors to Resist Management Pressure. The Accounting Review, 60(2), 202-11.

Kohlberg, L. (1981). The philosophy of moral development moral stages and the idea of justice.

Kraft, K. L., \& Singhapakdi, A. (1991). The role of ethics and social responsibility in achieving organizational effectiveness: Students versus managers. Journal of Business Ethics, 10(9), 679-686.

Kum-Lung, C., \& Teck-Chai, L. (2010). Attitude towards Business Ethics: Examining the Influence of Religiosity, Gender and Education Levels. International Journal of Marketing Studies, 2(1), 225-232.

Lee, C., \& Bobko, P. (1994). Self-efficacy beliefs: Comparison of five measures. Journal of Applied Psychology, 79(3), 364.

McPhail, K., \& Walters, D. (2009). Accounting \& Business Ethics (1st ed.). New York: Routledge.

Muawanah, U. (2000). Perilaku Auditor dalam Situasi Konflik Audit: Peran Locus of Control, Komitmen Profesi dan Kesadaran Etis. Universitas Gadjah Mada.

Muawanah, U., \& Indriantoro, N. (2001). Perilaku Auditor dalam Situasi Konflik Audit: Peran Locus of Control, Komitmen Profesi, dan Kesadaran Etis. Jurnal Riset Akuntansi Indonesia, 4(2).

Ponemon, L. A. (1992). Ethical reasoning and selection-socialization in accounting. Accounting, Organizations and Society, 17(3-4), 239-258.

Ponemon, L. A., \& Gabhart, D. R. L. (1990). Auditor independence judgments: A cognitive-developmental model and experimental evidence. Contemporary Accounting Research, 7(1), 227-251.

Purnamasari, V. (2006). Sifat Machiavellian dan Pertimbangan Etis: Anteseden independensi dan perilaku Etis Auditor. In Simposium Nasional Akuntansi IX. 
Rakhmat, J. (2007). Psikologi Komunikasi Edisi Revisi. Bandung: PT. Remaja Rosdakarya.

Reiss, M. C., \& Mitra, K. (1998). The Effects of Individual Difference Factors on the Acceptability of Ethical and Unethical Workplace Behaviors. Journal of Business Ethics, 17(14), 1581-1593.

Richmond, K. A. (2003). Machiavellianism and Accounting: An Analysis of Ethical Behavior of US Undergraduate Accounting Student and Accountants. In Symposium on Ethics Research in Accounting. American Accounting Association.

Robbins, S. P. (1997). Perilaku Organisasi (Judul asli: Organizational Behavior, Alih bahasa: Dr. Hadyana Pujaatmaka. Jakarta: PT. Prenhallindo.

Susanty, F. I. (2002). Pengaruh Gender dan Locus of Control Terhadap Evaluasi Etika Bisnis Akuntan Publik. Universitas Gadjah Mada.

Trevino, L. K. (1986). Ethical decision making in organizations: A person-situation interactionist model. Academy of Management Review, 11(3), 601-617.

Trevino, L. K., \& Youngblood, S. A. (1990). Bad apples in bad barrels: A causal analysis of ethical decision-making behavior. Journal of Applied Psychology, 75(4), 378-385.

Tsui, J. S. L., \& Gul, F. A. (1996). Auditors' behaviour in an audit conflict situation: A research note on the role of locus of control and ethical reasoning. Accounting, Organizations and Society, 21(1), 41-51.

Zoraifi, R. (2005). Pengaruh Locus of Control, Tingkat Pendidikan, Pengalaman Kerja, dan Pertimbangan Etis Terhadap Perilaku Auditor dalam Situasi Konflik Audit. Jurnal Akuntansi Dan Bisnis, 5(1), 12-26. 